\title{
Kepastian Dan Perbandingan Hukum Mengenai Saham Pinjam Nama Atau Nominee Shareholder Antara Indonesia Dan Thailand
}

\author{
Dipadary Abiyudara \\ Pascasarjana Fakultas Hukum Universitas Islam Indonesia Yogyakarta Indonesia \\ Jln. Cik Di Tiro No. Yogyakarta Indonesia \\ dipadaryuda@gmail.com
}

\begin{abstract}
The purpose of this study is to examine the legal certainty of nominee shareholder in Indonesia and the legal comparison between Indonesia and Thailand. This is a normative legal research with statutory and comparative approaches. The results of this study are first, the nominee shareholder violates 6 Indonesian laws, especially the articles in UUPM No. 25 of 2007, UUPT No. 40 of 2007, and the Civil Code. Second, there are 3 driving factors for nominee shareholders, namely the presence of foreign intentions to control state assets, the complexity of licensing foreign investment, and tax issues. Third, a comparative analysis of the UUPM, UUPT, and the RI BKPM Regulation No. 1 of 2020 with the Thailand Foreign Business Act 1999 found that Thailand imposes more severe and stricter criminal sanctions and supervisory policies than Indonesia. Indonesian law still provides loopholes for nominee practice.
\end{abstract}

Key Words: Legal comparison; nominee shareholder; shares under borrowed name

\begin{abstract}
Abstrak
Tujuan penelitian ini untuk mengkaji tentang kepastian hukum nominee shareholder di Indonesia dan perbandingan hukum antara Indonesia dan Thailand. Riset ini merupakan penelitian hukum normatif dengan pendekatan peraturan perundang-undangan dan komparasi. Hasil dari penelitian ini pertama, nominee shareholder melanggar 6 aturan hukum Indonesia, terutama pasal-pasal dalam UUPM No. 25 Tahun 2007, UUPT No. 40 Tahun 2007, serta KUHPerdata. Kedua, terdapat 3 faktor pendorong nominee shareholder yaitu adanya niat asing menguasai aset negara, kompleksnya perizinan investasi asing, dan isu perpajakan. Ketiga, analisis perbandingan UUPM, UUPT, dan peraturan BKPM RI No. 1 Tahun 2020 dengan Thailand Foreign Business Act 1999 menemukan bahwa Thailand memberlakukan sanksi pidana dan kebijakan pengawasan yang lebih berat dan ketat daripada Indonesia. Aturan hukum Indonesia masih menyediakan celah bagi praktik nominee.
\end{abstract}

Kata-kata Kunci: Nominee shareholder; saham pinjam nama; analisis perbandingan hukum 


\section{Pendahuluan}

Negeri ini memiliki salah satu pasar saham terbesar di Asia dengan 650 perusahaan terdaftar di Bursa Efek Indonesia (BEI). Nilai kapitalisasi pasar pada 2020 diprediksi mencapai hampir Rp. 7.500.000.000.000,00. Selain itu, data dari World Bank menunjukkan bahwa 52 juta dari 260 juta penduduk Indonesia merupakan masyarakat ekonomi kelas menengah yang mempunyai daya beli tinggi sehingga sangat potensial bagi investor asing untuk menanamkan modalnya di Nusantara. ${ }^{1}$ Ditambah lagi, pemerintahan saat ini berfokus pada pembangunan infrastruktur dan fasilitas transportasi yang kemudian mendatangkan banyak investasi asing ke dalam negeri. Dengan maraknya kedatangan asing untuk menanamkan modal dan berbisnis di Indonesia, salah satu kelemahan yang sering dikeluhkan oleh para pebisnis global adalah keterbatasan sektor dimana mereka dapat berinvestasi. Pemerintah Indonesia melalui Daftar Negatif Investasi (DNI) Peraturan Presiden No. 44 Tahun 2016, kemudian direvisi pada 2018 yang mengatur tentang daftar bidang usaha "tertutup" dan "terbuka" dalam bidang penanaman modal.

Selain keluhan di atas, Badan Koordinasi Penanaman Modal (BKPM) pernah menyebutkan bahwa beberapa hal penting lainnya yang kemudian mengurungkan niat investor asing untuk menginvestasikan dananya ke Indonesia, antara lain karena regulasi yang kompleks dan sering berganti, izin usaha yang berbelit, serta isu-isu perpajakan. Adanya pembatasan bidang usaha bagi pemodal asing, kompleksitas perizinan investasi asing, dan isu perpajakan membuat investor asing kemudian mencari celah dalam aturan hukum Indonesia untuk terhindar dari sebagian atau keseluruhan persoalan-persoalan di atas dan akhirnya melahirkan sebuah polemik baru yaitu munculnya praktik nominee shareholder di Indonesia.

Apabila dilihat secara teori, konsep nominee terdapat pada surat perjanjian yang dibuat antara Warga Negara Asing (WNA) dan Warga Negara Indonesia (WNI) dengan hakikat untuk mengalihkan segala kewenangan yang mungkin timbul dalam hubungan hukum kepada WNI sebagai penerima kuasa untuk bertindak layaknya sebagai pemilik sebenarnya atas suatu hal yang diperjanjikan. ${ }^{2}$ Praktik inilah yang dilakukan oleh pihak asing dengan meminjam nama WNI untuk mempunyai kontrol kepemilikan atas sesuatu. Konsep nominee yang terjadi di Indonesia digunakan dalam beberapa transaksi hukum, namun yang paling sering adalah praktik saham pinjam nama atau banyak dikenal dengan terminologi nominee shareholder.

1 https://www.cnbcindonesia.com/market/20200602201630-17-162584/10-negara-terbaik- Diakses 1 Juli 2020 .

2 Muhammad Taufiq Budiarto, "Sudut pandang perpajakan atas pengalihan hak tanah dan bangunan dengan mekanisme perjanjian nominee", Makalah disampaikan di seminar Simposium Nasional Keuangan Negara, Pusdiklat Pajak, 2018, hlm. 3. 
Terdapat beberapa alasan mengapa studi ini memilih Thailand sebagai pembanding aturan hukum mengenai nominee shareholder. Analisis perbandingan difokuskan pada aturan UUPM No. 25 Tahun 2007, UUPT No. 40 Tahun 2007, dan Peraturan BKPM No. 1 Tahun 2020 di Indonesia dengan aturan Foreign Business Act 1999 milik Thailand. Secara pokok, ada tiga hal utama yang menjadi dasar memilih Thailand sebagai objek penelitian. Pertama, Thailand memiliki kultur masyarakat, budaya, dan tingkat ekonomi yang relatif sama dengan Indonesia, terutama karena keduanya tergabung dalam regional Association of Southeast Asian Nations (ASEAN). Kedua, baik Indonesia maupun Thailand mendasarkan negaranya pada sistem civil law dan keduanya juga memiliki regulasi dan aturan hukum dalam Undang-undang yang melarang praktik nominee. Indonesia dan Thailand memiliki persamaan persepsi bahwa praktik nominee merupakan tindakan ilegal dan menyalahi hukum. Larangan praktik nominee shareholder diatur dalam beberapa Undang-undang dan peraturan, namun yang paling jelas mengatur dan dijadikan landasan adalah UU Penanaman Modal 2007 Pasal 33. Namun, yang sangat disayangkan adalah tidak adanya sanksi yang jelas yang ditulis dalam UUPM tersebut mengenai pelaku nominee.

Pada akhirnya, hakim yang kemudian menafsirkan UU dan peraturan lainnya untuk memutuskan perkara nominee di pengadilan. Apabila terbukti menyalahi aturan dan ditemukan tindakan penyelundupan hukum dari praktik nominee yang dilakukan oleh WNA dan WNI, maka dalam beberapa kasus, putusan pengadilan adalah memberi sanksi administratif, seperti pencabutan izin usaha serta membebankan denda bagi WNA atas kerugian-kerugian yang ditanggung oleh Negara. Besaran denda kemudian disesuaikan sesuai dengan kepelikan perkara dari kasus yang ditangani tersebut. Pada umumnya, WNA sebagai pihak beneficiary saja yang kemudian dikenakan sanksi denda atas kerugian tersebut.

Hal ini sangat berbeda dengan yang dilakukan oleh Thailand. Negara tersebut mengatur secara spesifik dan menerapkan sanksi yang berat bagi pelaku yang melanggar ketentuan dalam Foreign Business Act 1999 Pasal 36, Pasal 37, Pasal 38, dan Pasal 41. Pelaku praktik nominee agreement tersebut akan mendapatkan sanksi yang tegas, antara lain hukuman penjara tidak lebih dari tiga tahun, atau denda dari 100.000 Baht sampai 1.000.000 Baht, atau keduanya, yaitu hukuman penjara dan denda. Pengadilan kemudian akan mengeluarkan surat perintah berupa penghentian operasi bisnis, atau pembubaran bisnis, atau memerintahkan penghentian kepemilikan saham atau kemitraan. Pelanggar perintah Pengadilan tersebut akan dikenakan hukuman dengan denda 10.000 Baht hingga 50.000 Baht per hari selama sampai perintah tersebut dilakukan. 


\section{Rumusan Masalah}

Berdasarkan pada latar belakang di atas, rumusan masalah yang akan dibahas dalam penelitian ini antara lain: pertama, bagaimana kepastian hukum dari praktik nominee shareholder yang ada di Indonesia? Kedua, bagaimana perbandingan aturan hukum mengenai nominee shareholder yang diterapkan di Indonesia dan Thailand?

\section{Tujuan Penelitian}

Sesuai dengan rumusan masalah yang telah disebutkan sebelumnya, penelitian ini bertujuan untuk: pertama, menganalisis kepastian hukum dari praktik nominee shareholder yang ada di Indonesia ditinjau dari peraturan perundang-undangan yang berlaku. Kedua, menganalisis perbandingan aturan hukum dan kebijakan pemerintah Indonesia dan Thailand dalam mengatur dan mengawasi praktik nominee yang ada di kedua negara tersebut.

\section{Metode Penelitian}

Penelitian ini termasuk dalam penelitian hukum normatif dengan menggunakan dua pendekatan, yaitu statute approach dan comparative approach. ${ }^{3}$. Oleh karena itu, studi ini secara lebih spesifik akan menganalisis peraturan perundang-undangan dalam mengatur praktik nominee shareholder di Indonesia.4 Selain itu, peneliti juga membandingkan perundangan, aturan hukum, peristiwa hukum, dan kebijakan terkait nominee shareholder di dua negara berbeda, yaitu Indonesia dan Thailand.

\section{Hasil Penelitian dan Pembahasan}

\section{Kepastian Hukum Praktik Nominee Shareholder yang Ada di Indonesia}

Nominee shareholder belum menjadi topik yang dibahas secara tegas dan khusus dalam UU KUHPerdata di Indonesia, namun dikarenakan oleh isi atau materi atau objek yang terkandung dalam perjanjian nominee adalah sesuatu hal yang tidak sesuai dan secara de jure melanggar ketentuan perundang-undangan yang berlaku di Indonesia, maka praktik ini secara otomatis akan menimbulkan berbagai permasalahan hukum. Terdapat 6 poin mengenai praktik nominee shareholder yang bertentangan dengan berbagai aturan hukum yang berlaku di Indonesia, seperti di bawah ini:

3 Soerjono Soekanto dan Sri Mamuji, Penelitian Hukum Normatif (Suatu Tinjauan Singkat), Rajawali Pers, Jakarta, 2001, hlm. 14

4 C.F.G Sunaryati Hartono, Penelitian Hukum di Indonesia pada Akbir Abad ke-20, Penerbit Alumni, Bandung, cetakan ke-2, 2006, hlm. 139. 
1. Pasal 33 ayat (1) dan ayat (2) Undang-Undang No. 25 Tahun 2007 tentang Penanaman Modal (UUPM)

Ayat 1 "Penanam modal dalam negeri dan penanam modal asing yang melakukan penanaman modal dalam bentuk perseroan terbatas dilarang membuat perjanjian dan/atau pernyataan yang menegaskan bahwa kepemilikan saham dalam perseroan terbatas untuk dan atas nama orang lain."

Ayat 2 "Bila penanam modal, baik dalam negeri maupun asing, membuat perjanjian dan/atau pernyataan yang menegaskan kepemilikan saham perseroan terbatas untuk dan atas nama orang lain sehingga menyebabkan adanya perbedaan pada kepemilikan saham perseroan terbatas secara normatif (nominee) dan secara substansial (beneficiary) maka perjanjian dan/atau pernyataan tersebut akan batal demi hukum.

Perjanjian nominee secara terang telah melakukan pelanggaran pada Pasal 33 ayat (1) dan (2) karena sesuai penjelasan yang ada pada bab-bab sebelumnya dari tesis ini yang menjelaskan bahwa WNI sebagai nominee bertindak dan berkelakuan seolah-olah pemilik sebenarnya dari suatu saham dan WNA sebagai pihak beneficiary memiliki kontrol penuh atas saham tersebut. Objektif dari praktik nominee yang dilakukan oleh keduanya membuat suatu saham atau perseroan terbatas secara normatif dimiliki oleh nominee, namun secara materi dan substansi dimiliki oleh beneficiary. Sehingga menurut kedua ayat pada pasal di atas, nominee shareholder dinyatakan batal demi hukum.

2. Pasal 48 ayat (1) Undang-Undang No. 40 Tahun 2007 tentang Perseroan Terbatas (UUPT).

"Saham Perseroan dikeluarkan atas nama pemiliknya."

Baik dalam perjanjian nominee langsung (direct nominee), maupun perjanjian nominee tidak langsung (indirect nominee), keduanya mempunyai tujuan serupa walau dengan cara yang berbeda, memindahkan kepemilikan saham nominee (WNI) kepada beneficiary (WNA) sehingga pihak asing mempunyai kendali penuh atas saham atau perusahaan tertentu. Poin ini secara jelas telah melanggar aturan hukum yang ada.

3. Pasal 52 ayat (1), (2) dan (4) Undang-undang No. 40 Tahun 2007 tentang Perseroan Terbatas (UUPT).

Ayat 1_"Saham memberikan hak kepada pemiliknya untuk:

a. menghadiri dan mengeluarkan suara dalam RUPS;

b. menerima pembayaran dividen dan sisa kekayaan hasil likuidasi

c. menjalankan hak lainnya berdasarkan Undang-Undang ini"

Ayat 2 "Ketentuan sebagaimana dimaksud pada ayat (1) berlaku setelah saham dicatat dalam daftar pemegang saham atas nama pemiliknya."

Ayat 4 "Setiap saham memberikan kepada pemiliknya hak yang tidak dapat dibagi."

Sebagai pemilik dari suatu saham, akan melekat padanya hak-hak yang terkandung dalam kepemilikan tersebut, di antaranya 3 poin seperti yang telah disebutkan pada Pasal 52 ayat (1) di atas. Namun demikian, perjanjian nominee yang dilakukan oleh WNI dan WNA telah melanggar 
Pasal 52 ayat (2) karena saham wajib tercatat atas nama si pemegang sahamnya, apabila nama pemegang saham berbeda dengan pemilik sebenarnya maka hal tersebut dilarang oleh hukum. Selain itu, perjanjian nominee juga melanggar Pasal 52 ayat (4) karena hak yang seharusnya menjadi hak tunggal pemilik telah dibagi dan bahkan pada mayoritas kasus, telah dipindahkan sepenuhnya dari nominee kepada beneficiary.

4. Pasal 1320 KUHPerdata

"Supaya terjadi persetujuan yang sah, perlu dipenuhi empat syarat;

a. kesepakatan mereka yang mengikatkan dirinya;

b. kecakapan untuk membuat suatu perikatan;

c. suatu pokok persoalan tertentu;

d. suatu sebab yang halal"

Pasal 1320 KUHPerdata ini menerangkan mengenai syarat sahnya suatu perjanjian, dimana terdapat 4 (empat) syarat yang harus dipenuhi agar di depan hukum perjanjian tersebut dapat dikatakan sah untuk dilaksanakan. Poin persyaratan ke-1 dan ke-2 dalam pasal di atas merupakan bentuk syarat subyektif yang mengandung pengertian yang apabila kedua syarat tersebut tidak dapat dipenuhi, maka perjanjian dapat dibatalkan. Sementara itu, poin persyaratan ke-3 dan ke-4 termasuk bentuk syarat obyektif yang apabila dilanggar maka perjanjian tersebut akan dinyatakan batal demi hukum. Bunyi pernyataan "suatu sebab yang halal" dalam isi poin syarat ke-4 mengandung maksud bahwa hal yang diperjanjikan harus memenuhi unsur berikut: a. Tidak dilarang oleh aturan perundangan yang berlaku di Indonesia, b. Tidak berlawanan dengan norma kesusilaan, dan c. Tidak mengganggu ketertiban umum.

5. Pasal 1335 KUHPerdata

"Suatu perjanjian tanpa sebab atau yang telah dibuat karena suatu sebab yang palsu atau terlarang, tidak mempunyai kekuatan". 5

Praktik nominee masuk ke dalam aturan pasal ini karena nominee shareholder, baik yang direct maupun yang indirect menjadi sebuah perbuatan subjek hukum yang terlarang karena telah jelas melanggar Pasal 33 ayat (1) dan (2) UUPM. Dengan demikian, nominee shareholder yang ditandatangani oleh pihak WNI dan WNA menjadi tidak berarti, tidak memiliki kekuatan, dan dinyatakan batal di mata hukum.

6. Pasal 1337 KUHperdata

"Suatu sebab adalah terlarang, jika sebab itu dilarang oleh undang-undang atau bila sebab itu bertentangan dengan kesusilaan atau dengan ketertiban umum"

Kausa suatu perjanjian dinyatakan bukan merupakan sebab yang halal sehingga terlarang apabila kausa tersebut menurut Pasal 1337 KUHPerdata merupakan kausa yang "dilarang oleh undang-undang atau apabila berlawanan dengan kesusilaan, baik atau ketertiban umum". Perjanjian seperti ini tidak boleh atau tidak dapat dilaksanakan sebab melanggar

${ }^{5}$ Herlien Budiono, Ajaran Umum Hukum Perjanjian dan Penerapannya di Bidang Kenotariatan, Citra Aditya Bakti, Bandung, 2011, hlm 73. 
hukum atau kesusilaan atau ketertiban umum sehingga perjanjian semacam nominee shareholder dengan sendirinya batal demi hukum.

\section{Perbandingan Aturan Hukum Mengenai Nominee Shareholder antara Indonesia dan Thailand}

Terdapat beberapa alasan mengapa tesis ini memilih Thailand dalam membandingkan aturan hukum praktik nominee shareholder dengan Indonesia. Terdapat beberapa persamaan fundamental dan juga beberapa perbedaan di antara kedua negara ASEAN ini dalam mengatur, merumuskan kebijakan, dan melaksanakan penegakan hukum untuk oknum yang melakukan praktik nominee. Berikut adalah 3 poin penting yang akan dianalisis dalam bagian ini:

\section{Sistem Hukum Indonesia dan Thailand Berlandaskan pada Civil Law}

Kedua negara ini menarik untuk diperbandingkan karena beberapa persamaan yang membuat keduanya memiliki relevansi untuk didiskusikan dengan lebih detail, di antaranya:

a. berada di kawasan regional ASEAN sehingga memiliki kultur masyarakat dan budaya yang sama-sama memegang pada gaya hidup, nilai luhur, kebiasaan, dan adat tradisional dengan ciri "ketimuran".

b. Walaupun secara total Gross Domestic Product (GDP) Indonesia memiliki besaran yang jauh lebih besar, namun secara rerata, level ekonomi masyarakat kedua negara ini seimbang dan masuk ke dalam kategori negara dengan prospek ekonomi yang baik.

c. Sistem hukum dan peradilan keduanya berlandaskan pada Civil Law dan bukan Common Law.

Menyinggung poin nomor 3 dengan lebih detail, adalah fakta penting bahwa kedua negara ini melandaskan sistem hukum mereka pada Civil Law. Hal ini dikarenakan, apabila tesis ini memilih negara lain yang menggunakan sistem Common Law sebagai pembanding, maka analisisnya menjadi tidak relevan dan seimbang. Demikian halnya oleh sebab beberapa negara yang menganut sistem Common Law seperti Amerika Serikat dan banyak negara Barat lainnya memperbolehkan praktik nominee, meskipun dengan ketentuan-ketentuan tertentu. Oleh sebab itulah, demi membuat perbandingan yang seimbang, tesis ini memilih negara Thailand untuk dibandingkan dengan Indonesia.

\section{Perbandingan Sanksi Hukum untuk Pelaku Praktik Nominee}

Indonesia dan Thailand memiliki persamaan persepsi bahwa praktik nominee merupakan tindakan ilegal dan menyalahi hukum. Larangan praktik nominee shareholder diatur dalam beberapa undang-undang dan peraturan, namun 
yang paling jelas mengatur dan dijadikan landasan adalah UU Penanaman Modal 2007 Pasal 33. Putusan pada aduan kasus-kasus nominee shareholder adalah secara normatif perjanjian-perjanjian nominee tersebut batal demi hukum. Namun, yang sangat disayangkan adalah tidak adanya sanksi yang jelas yang ditulis dalam UUPM tersebut mengenai pelaku nominee.

Pada akhirnya, hakim yang kemudian menafsirkan UU dan peraturan lainnya untuk memutuskan perkara nominee di pengadilan. Apabila terbukti menyalahi aturan dan ditemukan tindakan penyelundupan hukum dari praktik nominee yang dilakukan oleh WNA dan WNI, maka dalam beberapa kasus, putusan pengadilan adalah memberi sanksi administratif, seperti pencabutan izin usaha serta membebankan denda bagi WNA atas kerugian-kerugian yang ditanggung oleh Negara. Besaran denda kemudian disesuaikan sesuai dengan kepelikan perkara dari kasus yang ditangani tersebut. Pada umumnya, WNA sebagai pihak beneficiary saja yang kemudian dikenakan sanksi denda atas kerugian tersebut.

Hal ini sangat berbeda dengan yang dilakukan oleh Thailand. Seperti yang telah disebutkan sebelumnya mengenai aturan hukum nominee di Thailand, negara tersebut mengatur secara spesifik dan menerapkan sanksi yang berat bagi pelaku yang melanggar ketentuan dalam Foreign Business Act 1999 Pasal 36, Pasal 37, Pasal 38, dan Pasal 41. Pelaku praktik nominee shareholder tersebut akan mendapatkan sanksi yang tegas, antara lain Hukuman penjara tidak lebih dari tiga tahun, atau denda dari 100.000 Baht sampai 1.000.000 Baht, atau keduanya, yaitu hukuman penjara dan denda. Pengadilan kemudian akan mengeluarkan surat perintah berupa penghentian operasi bisnis, atau pembubaran bisnis, atau memerintahkan penghentian kepemilikan saham atau kemitraan. Pelanggar perintah Pengadilan tersebut akan dikenakan hukuman dengan denda 10.000 Baht hingga 50.000 Baht per hari selama sampai perintah tersebut dilakukan.

Begitu seriusnya pemerintah Kerajaan Thailand mengatur mengenai nominee shareholder terlihat dari sanksi hukum yang diatur tidak hanya terbatas bagi WNA saja, namun warga negara Thailand sendiri juga terkena imbasnya. Berbeda dengan putusan Indonesia yang seolah membebaskan WNI dari ancaman hukuman denda, di Thailand seluruh pelaku, apabila terbukti bersalah di mata hukum, akan menerima konsekuensi hukuman yang sama. Sehingga, efek jera tidak hanya dirasakan oleh WNA yang ingin bermain curang, tetapi juga WNI yang memfasilitasi dan berpartisipasi pada kegiatan penyalahgunaan hukum tersebut.

Apabila seseorang melakukan tindak penyelewengan hukum seperti yang diatur dalam Pasal 36, dan 37, 38, dan 41 FBA 1999 maka tidak hanya para pelaku yang terlibat atau yang namanya tertulis dalam nominee shareholder, seperti WNI 
(nominee) dan WNA (beneficiary) yang akan dikenai hukuman. Melainkan, direktur, partner, dsb yang mengetahui tentang tindakan ilegal tersebut, tidak mencegah terjadinya penyelundupan hukum, dan tidak melaporkannya kepada pihak yang berwajib, maka orang tersebut juga akan dikenakan sanksi pidana.

\section{Perbandingan Kebijakan Penegakan Hukum dan Upaya Pengawasan di Indonesia dan Thailand}

Kendala lemahnya penegakan praktik nominee adalah karena tindakan ilegal ini sangat sulit terdeteksi oleh aparat yang berwajib di Indonesia. Beberapa hal yang menyebabkannya adalah karena:

a. Perjanjian yang dibuat oleh beneficiary (WNA) dan nominee (WNI) seringkali berwujud indirect nominee sehingga perjanjian yang dibuat berlapis-lapis untuk menyembunyikan maksud dari perjanjian tersebut sebenarnya di mata hukum.

b. Belum adanya aturan hukum yang jelas mengenai praktik nominee serta lembaga atau satuan tugas khusus yang diberi tanggung jawab untuk melakukan kontrol dan pengawasan dengan wewenang yang kuat.

c. Sangat bergantung dengan delik aduan. Maksud dari poin ini adalah karena perihal mendeteksi adanya penyelundupan hukum melalui praktik nominee, mayoritas kasus yang sampai pada pengadilan adalah kasus-kasus dimana ada sengketa di antara pihak beneficiary dan nominee. Sehingga kemudian ada laporan yang masuk ke kepolisian yang kemudian diusut dan ditindaklanjuti hingga ke pengadilan.

Adapun penjelasan lebih detail mengenai poin c di atas mengenai sengketa antar 2 pihak seringkali berkait dengan beberapa permasalahan. Pertama, terdapat tindakan-tindakan atau keputusan-keputusan dari beneficiary yang harus dipenuhi oleh nominee, dimana bertentangan dengan keinginan nominee. Sehingga, pihak nominee bermaksud untuk menyudahi perjanjian tersebut. Kedua, pihak nominee melihat potensi untuk menguasai saham atau perusahaan yang sebenarnya milik beneficiary. Sehingga nominee melaporkan beneficiary kepada kepolisian agar saham yang diatasnamakan dirinya dapat dimiliki olehnya sepenuhnya, terutama karena mengetahui bahwa pengadilan akan memberikan hukuman atau sanksi-sanksi tertentu pada WNA.

Berbeda dengan Indonesia, pemerintah Thailand lebih agresif dalam melakukan pelacakan dan investigasi mengenai penyalahgunaan praktik nominee di Negara tersebut. Terdapat beberapa inisiatif yang dilakukan oleh pemerintah Thailand, yaitu:

a. Investigasi berkala untuk perusahaan domestik yang beroperasi di sektor yang dibatasi oleh pemerintah. 
Otoritas Thailand, baik dari kepolisian setempat maupun arahan dari Foreign Business Committee sesuai tugas yang diemban akan melakukan investigasi secara acak terhadap perusahaan-perusahaan yang berlabel Perusahaan Dalam Negeri namun bergerak di bidang-bidang yang dibatasi oleh Pemerintah Thailand untuk orang asing. Dalam investigasi berkala ini, pemerintah Thailand akan melakukan pengecekan bahwa memang tidak ada orang asing yang terlibat dalam perusahaan tersebut.

b. Investigasi berkala untuk perusahaan yang menempatkan akuntan atau pengacara pada posisi dewan direksi.

Berdasarkan pada kasus-kasus praktik nominee yang telah terjadi di Thailand, pemerintah memetakan bahwa dalam praktiknya banyak akuntan dan pengacara yang terlibat. Oleh karena itu, Thailand Foreign Business Committee, sebagai lembaga resmi pemerintah yang berhak mengeluarkan dan mengatur izin bisnis asing akan melakukan pemeriksaan berkala dan acak kepada perusahaan-perusahaan di Thailand dengan salah satu kriteria perusahaan yang diprioritaskan untuk diinvestigasi adalah perusahaan yang menempatkan akuntan ataupun pengacara dalam board of director. Biasanya, untuk menutupi bahwa pemilik sebenarnya dari suatu saham atau perusahaan adalah WNA, perusahaan akan menempatkan akuntan dan pengacara dalam dewan direksi di perusahaan tersebut karena mereka membutuhkan jasa profesional keduanya untuk mengaburkan fakta bahwa WNA adalah beneficial owner.

Poin b di atas menjelaskan mengapa Foreign Business Act 1999 Pasal 41 menyebutkan bahwa walaupun tidak terlibat secara langsung seperti menandatangani perjanjian nominee, dewan direksi, direktur, dan partner dalam perusahaan juga akan ikut dikenai sanksi hukum berupa ancaman hukuman sesuai yang UU yang berlaku. Hal itu dikarenakan pada praktiknya, dewan direksi, direktur, dan partner dalam banyak kasus di Thailand tidak hanya membiarkan tapi juga mengetahui dan bahkan memfasilitasi terjadinya praktik nominee dalam perusahaan tersebut. Hal ini adalah aturan yang sangat komprehensif yang diterapkan oleh Thailand, karena UU yang ada benar-benar dapat digunakan untuk menjerat seluruh komponen dan pihak-pihak yang terlibat sehingga tidak ada celah yang dapat dimanfaatkan oleh oknum-oknum yang dengan sengaja ingin mengelabui hukum.

c. Memberikan kewenangan yang kuat kepada Foreign Business Committee dan memasukkannya dalam aturan Undang-undang.

Keseriusan pemerintah Thailand dalam mengupayakan pencegahan dan prosedur yang ketat guna mengeliminasi praktik nominee shareholder adalah memasukkan aturan formal tertulis yang jelas ke dalam UU mengenai aturan 
Foreign Business Committee (FBC). Aturan tersebut meliputi siapa saja yang dapat menjadi anggota komite, karakteristik apa saja yang dibutuhkan, serta tugas dan wewenangnya. Berikut adalah beberapa pasal dalam Foreign Business Act 1999 yang membahas dengan detail mengenai FBC.

1. Pasal 23 dan 24 Foreign Business Act 1999

Pasal 23 "There shall be a Foreign Business Committee consisting of the Permanent Secretary of the Ministry of Commerce as the Chairperson, Representative of the Office of the National Economic and Social Development Board, Representative of the Office of the Board of Investment, Representative of the Ministry of Defence, Representative of the Ministry of Finance, Representative of the Ministry of Foreign Affairs, Representative of the Ministry of Agriculture and Cooperative, Representative of the Ministry of Transport and Communications, Representative of the Ministry of Interior, Representative of the Ministry of Labour and Social Welfare, Representative of the Ministry of Science, Technology and Environment, Representative of the Ministry of Industry, Representative of the Ministry of Education, Representative of the Ministry of Public Health, Representative of the Office of the Consumer Protection Board, Representative of the Royal Thai Police, Representative of the Thai Chamber of Commerce, Representative of the Federation of Thai Industries, Representative of the Thai Bankers Association and no more than 5 learned persons as appointed by the Minister as the Committee Members and the Director-General of the Commercial Registration Department shall be the Committee Member and Secretary.

The learned persons shall have the knowledge and expertise in economics, law, commerce, science, technology, environment, trade, investment, business administration, or industry and shall not be advisors to political parties or have any political position.

In the case where the representatives in Paragraph one are the representatives of government units, they shall have the positions that, in ranking, are not lower than Director-General position or equivalent thereof. And, in the case where they are the representatives of the Thai Chamber of Commerce, the Federation of Thai Industries, the Thai Bankers Association, they shall have the position ranking of not lower than a director of the Chamber, Federation or Association."

Pasal 24 "The learned committee members shall have the tenure of two years."

Pasal 23 di atas menjelaskan bahwa anggota yang termasuk dalam FBC harus terdiri atas representatif dari banyak Kementerian, seperti: (1) Ministry of Commerce; (2) Ministry of Defence; (3) Ministry of Finance; (4) Ministry of Foreign Affairs; (5) Ministry of Agriculture and Cooperative; (6) Ministry of Transport and Communication; (7) Ministry of Interior, Labour and Social Welfare; (8) Ministry of Science, Technology, and Environment; (9) Ministry of Industry; (10)

Pasal 23 juga mengatur bahwa anggota FBC harus memiliki keahlian-keahlian khusus sehingga asas profesionalitas dalam bekerja dapat menjadi kunci 
keefektifan fungsi dan tujuan dibentuknya komite ini. Berikut beberapa kualifikasi sebagai syarat yang harus dipenuhi oleh anggota FBC, yaitu mereka yang memiliki ilmu dan keahlian di bidang ekonomi, hukum, commerce, science, teknologi, lingkungan, perdagangan, investasi, administrasi bisnis, dan industri. Guna menjaga keprofesionalitasan, etos kerja, dan integritas yang tinggi, anggota FBC tidak boleh menjabat sebagai penasihat suatu partai politik atau mempunyai jabatan politik bersamaan dengan waktu jabatan sebagai anggota FBC, yaitu dalam kurun waktu 2 tahun.

Para anggota dari representasi seluruh lembaga di atas juga haruslah orang yang memiliki pangkat tinggi sehingga bisa memiliki wewenang untuk mengambil keputusan-keputusan penting yang berurusan dengan hukum. Hal ini dilakukan juga agar birokrasi dalam pengambilan keputusan menjadi lebih efektif dan efisien sehingga lebih cepat dalam mengusut suatu perkara.

2. Pasal 26 Foreign Business Act 1999

Pasal 26 "The Committee has the authority as prescribed in this Act and shall have the following duties: 1. Advising, recommending or giving opinions to the Minister on the enactment of royal decrees and issuance of ministerial regulations under this Act or the prescription of business category and business operation locality of the foreigners under Section 7 or the application for the Cabinet's approval under Section 8 (2). 2. Studying compiling, and preparing reports on the foreign business operation in Thailand including the impacts and appropriateness thereof, for presentations to the Minister from time to time but it shall not be less than once a year.3. Advising, recommending or giving opinions to the Minister on other matters as he may assign.

Pasal 26 pada FBA 1999 menerangkan dengan detail apa saja yang termasuk dalam tugas FBC, yaitu di antaranya memberikan nasihat, rekomendasi, dan pendapat kepada Menteri Perdagangan Thailand tentang pemberlakuan keputusan Kerajaan Thailand berdasarkan UU ini terkait pemberian izin usaha untuk WNA. FBC juga berwenang dalam mempelajari, menyusun, dan menyiapkan laporan tentang operasi bisnis asing di Thailand termasuk dampak dan kesesuaiannya terhadap aturan yang berlaku untuk kemudian dipresentasikan kepada Menteri secara berkala, minimal setahun sekali.

\section{a. Memberikan kewenangan yang kuat kepada Ministry of Commerce dalam menjalankan FBA 1999}

1. Pasal 29 Foreign Business Act 1999

Pasal 29 "The Commercial Registration Department, Ministry of Commerce, shall act as the Secretary Office of the Committee and shall have the following authority: 1. Performing work in accordance with the resolutions of the Committee or as assigned by the Committee; 2 . 
Presenting opinions to the Committee regarding the foreign business operation in Thailand for the benefit of the study, information compilation, and preparation of reports to the Minister; and 3. Performing general administrative work of the Committee."

2. Pasal 46 Foreign Business Act 1999

Pasal 46 "The Minister of Commerce shall be in charge and control of this Act and shall be empowered to appoint the registrars and competent officials and to issue the ministerial regulations prescribing the fees within the limits of the rates attached hereto as well as to give fee exemption and to designate other business to implement this Act."

Pasal 29 dan Pasal 46 di atas menempatkan Ministry of Commerce sebagai penanggung jawab, pengendali, dan pelaksana implementasi dari Undangundang ini. Selain itu, secara spesifik, representasi dari Ministry of Commerce harus menjadi Dewan Sekretaris dari FBC yang memiliki otoritas sebagai berikut: (1) mengerjakan sebagaimana ditugaskan oleh komite FBC; (2) Memberikan saran, rekomendasi, dan pendapat kepada FBC mengenai operasi bisnis asing di Thailand, guna kepentingan studi, analisis kompilasi informasi, dan persiapan laporan yang akan dipresentasikan kepada Menteri Perdagangan Thailand; (3) Melakukan pekerjaan administrasi umum untuk FBC.

Sebagai pelaksana dan penanggung jawab tertinggi dari FBA 1999, Menteri Perdagangan juga diberdayakan untuk menunjuk panitera (registrars) dan pejabat yang kompeten (competent officials) yang akan menjalankan tugas investigasi di lapangan.

\section{b. Memberikan kewenangan yang kuat kepada Registrars dan Competent Officials dan memasukkannya dalam aturan Undang- undang.}

1. Pasal 30 Foreign Business Act 1999

Pasal 30 "The Registrars and the Competent Officers shall have the authority:

1. To inquire in writing or summon any person for explanation of any facts, including submissions of documents or evidence necessary for verification of the facts; 2 . To enter the place where the foreigners operate the business during business hours to inspect and ensure the compliance with this Act provided an approval in writing must first be obtained from the Director-General except in case of utmost emergency. In performing the duty, they shall have the authority to inquire the facts or demand any documents or evidence necessary for the examination of the facts from the persons staying in the said place."

2. Pasal 31 Foreign Business Act 1999

Pasal 31 "If any person requests an examination or copy of the documents or requests the registrars to make copies or photocopies together with a certification thereof or requests the registrars to certify the statements kept by the registrar, the registrar shall rapidly grant a 
permission, except where the documents by its nature are prohibited by law governing official information or other laws from being disclosed. The applicant shall pay the fees as prescribed in the ministerial regulations."

3. Pasal 32 Foreign Business Act 1999

Pasal 32 "The competent officials must have identity cards in accordance with the form prescribed in the ministerial regulations. In carrying out the duty, the competent officials must present the identity cards to the persons concerned."

4. Pasal 33 Foreign Business Act 1999

Pasal 33 "In carrying out the duty under this Act, the Committee members, the Director-General, the registrars, the competent officials, and the persons carrying out the duty jointly with the competent officials shall be the competent officials under the Criminal Code."

Pasal 30, Pasal 31, Pasal 32, dan Pasal 33 dalam FBA 1999 memberikan penjelasan yang detail mengenai tugas registrars dan competent officials dalam menjalankan tugasnya sesuai arahan FBC dan peraturan perundangan yang berlaku untuk menginvestigasi da melakukan pengecekan bisnis secara berkala di lapangan.

Adapun otoritas yang diamanahkan kepada registrars dan competent officials meliputi: (1) Menanyakan secara tertulis atau memanggil siapapun dalam rangka mendapatkan penjelasan fakta, penyerahan dokumen atau bukti yang diperlukan untuk verifikasi fakta kepada entitas bisnis atau perusahaan yang sedang diinvestigasi; (2) Berwenang memasuki tempat di mana orang asing mengoperasikan bisnis selama jam kerja untuk memeriksa dan memastikan kepatuhan operasional sebagaimana yang diatur dalam FBA 1999; (3) Dalam melakukan tugas, mereka akan memiliki wewenang untuk menanyakan fakta atau meminta dokumen atau bukti yang diperlukan untuk pemeriksaan fakta dari orang-orang yang tinggal atau berada di tempat tersebut.

Sementara itu, Pasal 32 dan Pasal 33 FBA 1999 mengatur lebih lanjut mengenai prosedur dan aturan tata kerja dari registrars dan competent officials dalam menjalankan tugasnya di lapangan. Adalah sebuah kewajiban bagi competent officials untuk memiliki kartu identitas sesuai dengan formulir yang ditentukan dalam Peraturan Menteri. Dalam menjalankan tugasnya, pejabat yang kompeten juga harus menunjukkan kartu identitas tersebut kepada pihak yang diinvestigasi. Berdasarkan FBA 1999, seluruh anggota Komite, (FBC), Direktur Jenderal, registrars, competent officials dan orang-orang lainnya yang ditugaskan dalam menegakkan UU FBA 1999 ini harus mematuhi dan bekerja di bawah rambu-rambu criminal code untuk menjaga asas integritas dan keprofesionalan. 


\section{Penutup}

Penelitian ini telah mengidentifikasi bahwasanya praktik nominee shareholder telah melanggar 6 aturan hukum di Indonesia, antara lain: (a) Pasal 33 ayat (1 dan 2) UUPM No. 25 Tahun 2007; (b) Pasal 48 ayat 1 UUPT No. 40 Tahun 2007; (c) Pasal 52 ayat (1, 2, dan 4) UUPT No. 40 Tahun 2007; (d) Pasal 1320 KUHPerdata; (e) Pasal 1335 KUHPerdata; dan (f) Pasal 1337 KUHPerdata. Oleh karena itu, kesimpulan yuridis yang didapatkan dari kepastian nominee shareholder di mata peraturan perundangan Indonesia adalah memiliki konsekuensi hukum, yakni dinyatakan "batal demi hukum". Perbandingan aturan hukum mengenai nominee shareholder antara Indonesia dan Thailand difokuskan pada aturan UUPM No. 25 Tahun 2007, UUPT No. 40 Tahun 2007, dan Peraturan BKPM No. 1 Tahun 2020 di Indonesia dengan aturan Foreign Business Act 1999 milik Thailand. Terdapat beberapa poin perbedaan pada perundangan yang diterapkan antara kedua negara tersebut yang terangkum sebagai berikut: a. Sanksi hukum di Thailand lebih berat daripada di Indonesia. b. Sanksi pidana dikenakan pada seluruh pelaku nominee shareholder. c. Penegakan hukum nominee di Thailand lebih agresif daripada di Indonesia.

\section{Daftar Pustaka}

\section{Buku}

Soerjono Soekanto dan Sri Mamuji, Penelitian Hukum Normatif (Suatu Tinjauan Singkat), Rajawali Pers, Jakarta, 2001.

C.F.G Sunaryati Hartono, Penelitian Hukum di Indonesia pada Akhir Abad ke-20, cetakan ke-2, Penerbit Alumni, Bandung, 2006.

Herlien Budiono, Ajaran Umum Hukum Perjanjian dan Penerapannya di Bidang Kenotariatan, Citra Aditya Bakti, Bandung, 2011.

Muhammad Taufiq Budiarto, "Sudut pandang perpajakan atas pengalihan hak tanah dan bangunan dengan mekanisme perjanjian nominee", Makalah disampaikan di seminar Simposium Nasional Keuangan Negara, Pusdiklat Pajak, 2018

\section{Perundang-undangan}

Undang-Undang Nomer 8 Tahun 1995 tentang Pasar Modal

Undang-Undang Nomer 10 Tahun 1998 tentang Perubahan atas UU No. 7 Tahun 1992 tentang Perbankan

Undang-Undang Nomer 25 Tahun 2007 tentang Penanaman Modal

Undang-Undang Nomer 36 Tahun 2008 tentang Tarif Pajak Penghasilan (PPh)

Undang-Undang Nomer 40 tahun 2007 tentang Perseroan Terbatas f. KUHPerdata

Peraturan Pemerintah (PP) No. 302020 tentang Penurunan Tarif Pajak Penghasilan bagi Wajib Pajak Dalam Negeri yang Berbentuk Perseroan Terbuka 
Peraturan Presiden No. 44 Tahun 2016 mengatur tentang DNI, Peraturan BKPM Republik Indonesia No. 1 Tahun 2020 Tentang Pedoman Pelaksanaan Pelayanan Perizinan Berusaha Terintegrasi Secara Elektronik.

Thailand Foreign Business Act (FBA) 1999

\section{Online}

https://www.cnbcindonesia.com/market/20200602201630-17-162584/10-negara-terbaikinvestasi-saat-covid-19-ri-nomor-berapa, Akses 1 Juli 2020 